\title{
A NORMATIVE INSTRUMENT FOR ASSESSING THE MENTORING ROLE
}

\author{
KAREN JANSE VAN RENSBURG \\ GERT ROODT \\ gertr@uj.ac.za \\ Department of Human Resource Management \\ University of Johannesburg
}

\begin{abstract}
The objective of this study is to develop a normative instrument for assessing the mentoring role in the South African context. The sampling frame for the study constituted the 1200 employees of a division of a large transport organisation. A convenience sample including all 1200 employees yielded 637 fully completed records (a $53 \%$ response rate). First and second level factor analyses, followed by an iterative item analysis on the scale of 26 items, yielded a seemingly robust scale with a Cronbach alpha of 0,97 . The psychometric properties of the scale are further discussed.
\end{abstract}

\section{OPSOMMING}

Die doel van hierdie studie is om 'n normatiewe instrument te ontwikkel vir die beoordeling van die mentorskaprol in die Suid-Afrikaanse konteks. Die steekproefraamwerk vir die studie bestaan uit die 1200 werknemers van ' $n$ divisie uit 'n groot vervoeronderneming. 'n Gerieflikheidsteekproef wat al 1200 werknemers ingesluit het, het 637 volledigvoltooide rekords opgelewer ('n responskoers van 53\%). Eerste- en tweedevlakfaktorontledings gevolg deur 'n iteratiewe itemontleding op die 26 items van die skaal het 'n oënskynlike robuuste skaal met 'n Cronbach alfa van 0,97 opgelewer. Die psigometriese eienskappe van die skaal word verder bespreek.

Organisation socialisation - the process of introducing new members into the organisation and thereby entrenching the organisational culture and values - is an often underestimated tool for improving organisational effectiveness and efficiency, especially in a diverse work-force context such as South Africa. Organisation socialisation can be divided into three stages, namely:

- the pre-contract (also called the pre-arrival) stage,

- the induction (or the encounter) stage; and

- the role management (or the adjustment) stage (cf. Ivancevich \& Matteson, 1996).

Mentoring is an integral part of this socialisation process, (in the second and third stages where the first encounter and the adjustment takes place) (Storm \& Roodt, 2002) and is crucial for socialising new members (Kram, 1985) into the organisation. Mentoring is amongst others a training and development tool to assist individuals in the upward progression in companies (Levinson, Darrow, Klein, Levinson \& McKee, 1978; Roche, 1979). Mentoring is also a mechanism by which employees are equipped to adapt to organisational change (Eby, 1997). Interestingly, research has shown that maximum benefit may be achieved in the mentoring process, where the protégé is driving the process (Clutterbuck \& Abbott, 2003). The development of a measure for assessing the mentoring role may therefore be an important aid in identifying and developing suitable candidates for the mentoring role. The purpose of the study is therefore to develop such a measuring instrument.

\section{The origins of mentoring}

The description of mentoring can be traced back to ancient Greek mythology (cf. April, 1979; Chao, 1997; Chao, Walz \& Gardner, 1992; Clawson, 1980, 1985; Rogers, 1992). Most of the empirical research has been conducted in the last two decades, but this research is fragmented (Chao, 1997; Chao et al., 1992). Some of this research includes phases of mentoring (Kram, 1983, 1988), functions served by the mentor (Noe, 1988a; Orth, Wilkinson \& Benfari, 1987; Schockett \& Haring-Hidore, 1985; Tack \& Tack, 1986), and the outcomes of mentoring (Chao et al., 1992; Dreher \& Ash, 1990; Fagenson, 1988, 1989; Hunt \& Michael, 1983; Jacobi, 1991; Orpen, 1995; Riley \& Wrench,

Requests for copies should be addressed to: Gert Roodt, gertr@uj.ac.za
1985; Scandura, 1992; Whitely, Dougherty \& Dreher, 1991). Research also focuses more on the protégé. Some studies have been conducted on the mentor per se (Allen, Poteet \& Burroughs, 1997). Fagenson (1994) suggested that a multiperspective approach be followed to include both the mentor and the protégé.

Mentoring is a process of transferring specific knowledge from the mentor to the protégé (Hendrikse, 2003). This knowledge has two components, namely tacit and implicit knowledge. Tacit knowledge is knowledge that you can see or show. Implicit knowledge comes from years of practical experience and the mentor can only demonstrate this knowledge. Part of the knowledge transfer includes knowledge of the organisation (organisation culture)(Hendrikse, 2003). Singh, Bains and Vinnicombe (2002) supported this and according to them, this is crucial for organisational effectiveness and success.

Kram (1988) identified four phases of mentoring:

- Initiation. A younger person (protégé) is flattered that someone with a high level of management chooses him/her and the manager is pleased that someone younger seeks his/her advice. This normally has a timeframe of six months to a year.

- Cultivation. The mentor/protégé relationship develops symbiotically over this period. The timeframe is normally two to five years.

- Separation. The protégé outgrows the need for a mentor. The timeframe is over a period of six months to two years.

- Redefinition. The relationship develops to such an ideal level that these two parties are on a peer level.

Hunt and Michael (1983) referred to the four stages of mentoring as initiation, protégé learning, break-up and lasting friends. Chao (1997) supported Kram's sequence of the four mentoring stages and indicates that the protégés in the initiation phase report the lowest levels of support compared to the protégés in other phases.

The timeframe of mentorship is important and Cohen (1999a 1999b) also divided it into four phases, namely the early, middle, latter and final phases, which support Kram's (1988) phases. 
Besides the different stages of mentorship, one can also identify different types of mentoring. The next section deals with types of mentoring.

\section{Types of mentoring}

Five types of mentoring can be identified from the literature, namely hierarchical, peer, diversity, supervisory and executive mentoring that can be applied in different contexts.

\section{Hierarchical mentoring}

Hierarchical mentoring can be divided in mentors on a higher or lower grade:

\section{Mentoring from a higher grade}

Hierarchical mentoring is when a senior person (mentor) with regard to age and experience agrees to share his/her information, advice and emotional support with a junior person (protégé) (cf. April, 1979; Burke, 1983; Levinson et al., 1978; Olian, Carroll, Giannantonio \& Feren, 1988; Phillips-Jones, 1982; Walbrugh \& Roodt, 2003). Hunt and Michael (1983); Kram (1988); Levinson et al. (1978); Noe (1988a) and Owen (1991) were in favour of the aforementioned and refer to mentoring as a junior-senior relationship where the common purpose for both parties is the personal growth of the junior person.

\section{Mentoring from a lower grade}

According to Clutterbuck and Abbott (2003), the focus has recently been on relevant experience rather than on hierarchy level and therefore upward mentoring can occur where a junior employee mentors the senior manager, for example, on diversity issues.

\section{Peer mentoring}

Eby (1997) and Kram and Isabella (1985) were of the opinion that the traditional mentor-protégé relationship had to adjust to accommodate the flatter structures and this has led to lateral (peer) mentors. Clutterbuck and Abbott (2003) were in favour of peer mentoring. Kram and Isabella (1985) differentiated between information, collegial and special peer mentoring:

- Information peer mentoring is when an exchange of information occurs in the workplace, with less commitment involved.

- Collegial peer mentoring occurs when information exchange is linked to increasing levels of emotional support.

- Special peer mentoring entails an intimate relationship with a peer, which is scarce and takes years to develop.

When assisting in job-related skills development, intra team, inter team, co-worker, survivor mentoring, peer mentoring for domestic relocaters and international forms of mentoring can be used. When assisting in career skills development, internal and external collegial peer mentoring can be useful (Eby, 1997).

\section{Diversity mentoring}

There are two types of diversity mentoring, namely crosscultural and cross-gender mentoring:

\section{Cross-cultural mentoring}

Ndlovu, the Executive Manager of the Black Management Forum, suggests inter-cultural mentorship programmes, whereby whites and blacks can learn from each other. He also agrees that women could have more problems if black men were ruling (Alperson, 1993).

According to Atkinson, Neville and Casas (1991) and Thomas (1990), blacks are more likely to be in cross-race relationships than whites. White protégés on the other hand rarely form crossrace mentoring relationships (Thomas, 1990). Gunn (1995) suggested that the partners must also be trained in the sensitivity of the cross-cultural mentor-protégé relationship. Blacks were also more likely to find positive mentor relationships outside the department with other races than mentors of the same race (Thomas, 1990). According to Wingrove (2002), a short-term solution for protégés could be to get a role model in the black empowered group outside the company. Thomas and Alderfer (1989) found in their study that black people found it necessary to have white sponsorship, but also needed to have a mentoring relationship with a same race individual.

\section{Cross-gender mentoring}

In a study conducted by Olian et al. (1988), no consistent evidence of same sex mentor preferences (preference of male protégé to male mentor) was found. Ragins and Cotton (1999) and Ragins and McFarlin (1990) found that cross-gender mentoring leads to less social activities than same gender mentoring. Noe (1988a) indicated that protégés in cross-gender mentor relationships utilised these relationships more effectively than protégés of the same sex mentor relationship.

The problem is that there are only a few women in top management positions (Blau \& Ferber, 1987; Ueckermann, 2004) that can act as role models (Bowen, 1985; Ragins \& Scandura, 1994; Warihay, 1980). Other researchers have also found this shortage of female mentors (Brown, 1986; Noe, 1988b; Parker \& Kram, 1993; Ragins, 1989). Junior female employees experience less support from the top women than the top women managers feel they render to the juniors (Warihay, 1980).

Brefach (1986) and Erkut and Mokros (1984) found that both genders see men as having more power and Erkut and Mokros (1984) found that male protégés avoid female mentors because of this. Rogers (1992) referred to the mentoring circles (e.g. one mentor for three protégés) to assist females and focus on gender awareness in mentoring. Kayle and Jacobson (1995) referred to this as group mentoring.

Everybody must be able to have access to mentoring opportunities with senior managers, and cross-gender mentorship creates an environment to make this possible for young women (Kram, 1988). According to Bowen (1985), both male mentors and female protégés benefit positively in their work or non-work relationships and this outweighs the problems that can be experienced.

As more women enter the business world, the pressures of tokenism are reduced and women can therefore be free from the stress of being the only one in this business environment (Kanter, 1977). Secondly, as more women enter the managerial levels, there will be female mentors available and role modelling will be easier (Daily, Certo \& Dalton, 2000; Kram, 1988). Blake (1995) conducted a study on black women and found that they lack black role models and this causes frustration. They did not trust white women and this affected their relationships.

\section{Supervisory mentoring}

Only a few studies have focused on supervisory mentoring (Douglas \& Schoorman, 1988; Scandura \& Schriesheim, 1994). Burke, McKenna and McKeen (1991) suggested that the quality of mentoring would be affected by a protégé's status. Scandura and Schriesheim (1994) found that supervisory mentoring was linked to higher salary and promotion rates for subordinates. Mullen (1994) suggested that protégés who have bosses as mentors communicate more comfortably with them.

When the supervisor/manager is the mentor, the protégés are likely to adopt the leadership style of their manager if the managers are perceived to be competent and respected (Bass, 1990). According to Burke, McKeen and McKenna (1993) and Ragins and McFarlin (1990) the advantage of having a boss as a mentor is that they receive more opportunities for career development. Fagenson-Eland, Marks and Amendola (1997) supported the results of Ragins and McFarlin (1990) that supervisory mentors were perceived as providing more effective mentoring than non-supervisory mentors.

In a study conducted by Green and Bauer (1995) on doctoral students and their advisors, they found that students who had higher verbal aptitude and commitment to the programme, 
received higher levels of psychosocial and career mentoring functions by their supervisors (advisors). Thus, the most talented students gained the most from the mentoring functions.

Women are also more likely than men to develop mentoring relationships with their supervisors as a result of male barrier networking (Brass, 1985). It seems that supervisory mentoring is increasingly becoming a part of the supervisor role (Green \& Bauer, 1995; Hissong, 1993; Kerkes, 1994; Marien, 1992; Parson, 1991).

\section{Executive mentoring}

Informal mentoring is normally applicable to executives and directors (April, 1979; Clutterbuck \& Megginson, 1999). In a study completed on women, executive women perceived the mentor as an important tool in assisting them in becoming more visible to top management and helping them to learn how to handle organisational politics. Most of these relationships were informal (Clutterbuck \& Devine, 1987). An increasingly common practice has recently been that the retiring Chief Executive Officer becomes a mentor to his/her successor (Clutterbuck \& Megginson, 1999). A word of caution was raised against self-styled gurus who make themselves available for coaching/mentoring and it was recommended that protégés do their homework before engaging in such a relationship (April, 1979).

Executive mentors can play the following roles, e.g. be a sounding board, critical friend, counsellor, career advisor, networker and coach. The protégé expects a mentor to play three common roles, namely executive coach, elder states person and reflective mentor (Clutterbuck \& Megginson, 1999). According to Clutterbuck and Megginson (1999), an important part of mentoring is the management of emotional intelligence. According to Goleman (1996), emotional intelligence involves five key skills:

- Knowing one's emotions (self-awareness).

- Managing emotions (handling feelings).

- Motivating oneself.

- Recognising emotions in others (empathy).

- Handling relationships (social competence).

The mentor can assist the protégé in obtaining these five skills. Part of the complexity of executive mentoring is the different processes involved as well as the fact that the mentor must assist on several levels to adhere to the protégé's needs. A model including different executive mentoring processes such as business processes, concepts and models, business results, selfawareness, intellectual leadership processes, behaviour, and emotional processes and values was developed by Clutterbuck and Megginson (1999).

Some of the qualities a mentor can have are experiences outside the organisation, asking good questions, role modelling, credibility, good listening skills, patience, networking, balancing processes and content, helping to manage knowledge and being dependable (Clutterbuck \& Megginson, 1999).

Against the background of the different types of mentoring relationships, the next section of the discussion will deal with critical issues in the mentor-protégé relationship.

\section{The mentor-protégé (mentoring) relationship}

The allocation of a mentor can be done formally or the protégé can informally choose a mentor (Fracaro, 2002; Hofmeyer, 1987; McGregor, 1993). There was a debate earlier on whether the informal mentor/protégé relationship can be formalised. Hofmeyer (1987) was of the opinion that due to the natural development of the mentor-protégé relationship over time, this relationship cannot be institutionalised (or formalised as a relationship), but organisations can try to create conditions to develop such relationships. Burke and McKeen (1989); GeigerDuMond and Boyle (1995) and Zey (1985) mentioned that organisations attempt to replicate informal mentoring into formal mentoring programmes. According to Kram (1985), mentoring affects the whole organisation and if everybody is committed (spends time, patience and effort) it is much more useful than a formal programme with little relevance for the individual and the organisation. Fracaro (2002); Ragins and Cotton (1999) and Viator (2000) supported the notion that informal mentoring has more benefits for the protégé than formal mentoring.

Time is the criteria for choosing between formal and informal mentoring. Organisations do not have the time to wait for the development of the relationship and therefore choose a formal mentoring programme (Hunt, 1991). Douglas (1997); Murray (1991) and Zey (1985) indicated that formal mentoring is less time consuming than informal mentoring. Dinsdale (1990) emphasised the fact that formal mentoring does not attempt to replace the informal process, but rather supplement it. According to Dinsdale (1990), these formal mentoring programmes should be flexible for protégés to select mentors other than supervisors and managers.

Chao et al. (1992) compared the formal and informal mentoring relationships. They found that protégés in informal mentoring relationships benefited more in terms of career-related support than protégés in formal mentoring relationships, but no differences were found in psychosocial support. The importance of their discovery was that regardless of the mentoring relationship, mentoring was beneficial to the individual (higher organisation socialisation, job satisfaction and salary). In contradictory results, Fagenson-Eland et al. (1997) found that protégés received greater psychosocial mentoring in informal mentoring and that formal mentoring did not influence the perceptions of career mentoring.

Informal mentoring develops spontaneously without the involvement of the organisation (Chao et al., 1992). Through programmes the company manages formal mentoring. McGregor (1993) supported the concept of formal mentoring and suggested that formal mentoring in organisations has manifested itself in training programmes and that the success of an employee development programme (such as affirmative action or mentoring programmes) depends on the mentor as well as the training and commitment of both sides (McGregor, 1993). It is important to note that the protégé must also take responsibility and initiatives for activities in the above-mentioned programme and part of this programme includes keeping a protégé's journal (Cohen, 1999a). The formal programmes also lead to additional organisation commitment from the mentor and the protégé (Phillips-Jones, 1983).

Matching the right mentor and protége is critical for the success of the mentoring (Cohen, 1999a). In this regard, the informal mentoring relationship is more positive because in a formal mentoring relationship, the programme coordinator decides on the match (Chao et al., 1992; Douglas, 1997; Gaskill, 1993; Murray, 1991; Singh et al., 2002). Possible criteria for successful matching range from working out the logistics of "who can meet when" to finding the "ideal" match. Gender, ethnicity (Burke, 1984; Thomas, 1990) and religion (Cohen, 1999a) are important variables. One viewpoint is also that the more similar the participants' background, the greater the chance of personal and professional compatibility. The background similarities were supported by Furano, Roaf, Styles and Branch (1993); Garcia (1992) and Ragins (1997). Ensher and Murphy (1997) found that the more protégés perceived themselves as being "similar" to the mentor, the more they would like the mentor and be satisfied with the mentor, and the more contact there would be. A "similar" concept in mentoring was supported by Allen et al. (1997) and Burke et al. (1993). Clutterbuck and Abbott (2003) were more in favour of differences rather than similarities, because more learning occurs in such a relationship.

The mentor will also be more attracted to higher performers than moderate performers (Fracaro, 2002; Olian, Carroll \& 
Giannantonio, 1993; Willbur, 1987). According to Fagenson (1992), the mentor-protégé relationship is based on mutual attraction and respect, while anticipated satisfaction is the key of this attraction (Olian et al., 1988).

One key aspect of the mentor-protégé relationship is trust (Clawson, 1980; Cohen, 1999b) and according to Hunt (1991), trust is critical irrespective of formal or informal mentoring. Hendrikse (2003) supported this and, according to him, if change occurs in the organisation it can have an impact on the mentor-protégé relationship.

Another key aspect of the mentor-protége relationship is interpersonal communication and both parties should listen affectively (Kram, 1988). Clawson (1980) indicated that effective mentors communicate more frequently with their protégés. Managers with greater levels of interpersonal skills are more often preferred as mentors (Olian et al., 1988)

With a better understanding of the mentoring relationship, the next section will more specifically focus on the mentoring role.

The mentoring role

Cohen $(1999 a, 1999 b)$ referred to six dimensions of the mentoring role. These six dimensions are incorporated in the behavioural profile for both the mentor and the protégé and provide the key thrust for each dimension (Cohen, 1999a) (See Table 1).

\section{TABLE 1}

BehaVIOURAL PROFILE OF A MENTOR AND PROTÉGé

Behavioural Profile

Mentor behaviour

Protégé behaviour

1. RELATIONSHIP

Key point - Trust

Shares and reflects on experiences.

Listens empathetically.

Understands and accepts.

Offers detailed explanations. Expects mentor to listen and to ask questions.

2. INFORMATION

Key point - Advice

Offers facts about career, education, Provides facts and records.

plans, progress. Expects mentor to review use

Comments about use of information. and depth of sources.

Exhibits tailored, accurate and

sufficient knowledge.

3. FACILITATIVE

Key point - Alternatives
Explores interests, abilities, ideas and beliefs

Provides other views/attainable goals.

Shares personal decisions about career.

Explains choices and decisions. Expects mentor to pose options and other views.

Key point - Challenge

Shows respect for decisions, actions,

career.

strategies and behaviours.

Evaluates need and capacity to change.

5. MENTOR MODEL

Key point - Motivation

Discloses life experience as role model. Expresses main concerns.

Personalises and enriches relationship. Expects mentor to share ideas

Takes risks; overcomes difficulties in and feelings.

education and career.

6. EMPLOYEE VISION

Key point - Initiative

Thinks critically about career future. Visualises own future.

Considers personal/professional potential.

Initiates change: Negotiates transitions.

Expects mentor to examine goals and approach.

Expects mentor to examine
4. CONFRONTATIVE

Shares insight into counterproductive

Kram (1988) identified nine mentoring roles which will serve as the theoretical framework of the instrument developed in this study. According to Kram (1988) these roles can be categorised into two dimensions, namely career functions (sponsorship, exposure and visibility, protection and challenging work assignments) and psychosocial functions (role modelling, acceptance and conformation, counselling and friendship). Each of the nine roles will be briefly described:

- Protection - providing protection to the protégé on risky issues within the organisation;

- Challenging tasks - assigning challenging tasks for growing the protégé's experience and competence;

- Counselling - encouraging open communication on the protégé's anxiety and fears that may hamper work performance;

- Coaching - introducing alternative ways of behaving on the job to the protégé;

- Friendship - being a best friend to the protégé;

- Sponsorship - acting as a sponsor to promote the career interests of the protégé;

- Exposure/visibility - providing exposure to the protégé through networking with other managers in the organisation;

- Acceptance - showing feelings of respect to the protégé; and

- Role model - serving as a role model to the protégé.

It becomes evident from the above descriptions that the mentor provides two types of support to the protégé, namely instrumental support (protection and challenging tasks) and psychosocial support (counselling, coaching and friendship) (Ensher \& Murphy, 1997) that also support Kram's nine roles. The studies that support Kram's work include Burke (1984); Gibb and Megginson (1993); Noe (1988a); Olian et al. (1988); Scandura (1992) and Schockett and Haring-Hidore (1985). The psychosocial support to which Kram (1988) referred includes help through the managers' network of relationships, which can also include peers (Kram \& Isabella, 1985).

From the above section it should be clear that mentoring is an important tool in the development of managerial capacity in organisations. It has a multitude of applications in a diverse work-force context and can make a large contribution to organisational effectiveness and efficiency.

\section{Problem statement}

South Africa is currently facing a serious shortage of competent and experienced managers, especially in the ranks of black managers. It seems that mentoring can play an important role in developing the required skills in these ranks. An instrument for assessing the mentoring role can be an important tool in identifying and developing mentors. The objective of this study therefore is to develop a normative instrument for assessing the mentoring role in the South African context.

\section{RESEARCH DESIGN}

\section{Research approach}

The research approach followed in the study is from the quantitative paradigm and the application of measuring instruments in a cross-sectional, non-random field survey generated the primary data for the study. An ex post facto approach to data analysis was used in exploring the interrelationships between variables in the data set.

\section{Research methodology}

The research methodology followed, is described according to the following three headings: plans and encourage progress.

[Adapted from Cohen, 1999a.]

\section{Sample of participants}

The largest division of a large transport organisation was targeted from a sampling frame of 1200 employees yielded 637 completed for the research. A convenience sample including all employees 
questionnaires. A response rate of 53\% was obtained. Only fully completed records were used for the data analyses.

As indicated in Table 2, the majority of the respondents were Whites (62\%) followed by Africans (24\%) and Coloureds/ Indians/Asians $(13,5 \%)$. Most of the respondents were male $(80,5 \%)$ and a smaller group $(19,5 \%)$ female.

TABLE 2

BACKGROUND INFORMATION OF THE RESPONDENTS

\begin{tabular}{lc}
\hline Background Information & Respo \\
\hline Race & \\
Africans & 1 \\
Coloureds/Indians/Asians & 8 \\
Whites & \\
TOTAL & \\
Gender & 6377 \\
Males & \\
Females & 5 \\
TOTAL & 1243 \\
& 637 \\
Age & \\
30 years and younger & \\
31-35 & 104 \\
36-40 & 9 \\
$41-45$ & 82 \\
$46-50$ & 141 \\
Older than 50 & 115 \\
TOTAL & 103 \\
\end{tabular}

Tenure

10 years or less

11-20 years

21-25 years

26-30 years

More than 30 years

TOTAL

Marital Status

Single, divorced or widowed

Married or living together

TOTAL

$\begin{array}{ll}171 & 26,8 \\ 466 & 73,2\end{array}$

Educational Level

Standard 9 or lower

Standard 10

Post-matric diploma/certificate

Degree or higher

TOTAL

\section{4}

86
397

637

513

124

104

92

141

115

637

158

130

124

100
125

637

466

637

131

179

218

109

637

Home Language

Afrikaans

English

African

TOTAL

Job level

Junior employees

Management

TOTAL

Union Membership

Do not belong to a union

Belong to a union

TOTAL

\section{Type of Mentor}

Hierarchical mentor in a higher grade

Hierarchical mentor in a lower grade

Supervisor as mentor

Peer mentor (same grade)

Executive mentor

No mentor

TOTAL

\section{Mentor Type}

Same race

Different race

Same sex

Opposite sex

No mentor

TOTAL
$100 \%$

24,2

13,5
62,3

$100 \%$

80,5

19,5

$100 \%$

16,3

14,4

12,9

22,1

18,1
16,2

$100 \%$

24,7

20,4

19,5

15,7
19,7

$100 \%$

$100 \%$

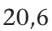

28,1

34,2

17,1

$100 \%$

50,2

25,4

24,4

$100 \%$

73

.

18,7

1,7

1,7
13,8

4,7

2,1

59

$100 \%$
Mentor Phase

Initial

Learning

Independency

Redefinition

No mentor

TOTAL

$\begin{array}{cc}61 & 10 \% \\ 72 & 11 \% \\ 64 & 10 \% \\ 64 & 10 \% \\ 376 & 59 \% \\ 637 & 100 \%\end{array}$

Mentor Age

$<25$

25-30

31-35

36-40

$41-45$

46-50

$51-55$

56-63

No mentor

TOTAL

\begin{tabular}{cc}
6 & $1 \%$ \\
17 & $3 \%$ \\
41 & $6 \%$ \\
31 & $5 \%$ \\
61 & $10 \%$ \\
45 & $7 \%$ \\
45 & $7 \%$ \\
15 & $2 \%$ \\
376 & $59 \%$ \\
637 & $100 \%$ \\
\hline
\end{tabular}

Measuring instrument

A comprehensive measuring instrument was designed for the purpose of another study (Janse van Rensburg, 2004). This questionnaire, the Employee Commitment Questionnaire, consisted of 127 items measured on a five-point intensity scale (excluding the biographical questions).

The mentioned questionnaire consisted of seven sections: Section $\mathrm{A}$ and $\mathrm{B}$ - the background information of the respondents; Section $\mathrm{C}-\mathrm{F}$ consisted of different scales that will not be discussed here; and Section G - The Mentorship Role Questionnaire - a 29 item questionnaire which was used for the purpose of this article. The latter scale was designed by the authors.

The questionnaire will be discussed in more detail next focussing on the rationale for inclusion in the study, the composition of the questionnaire as well as the reliability and validity of the instruments.

\section{The Mentorship Role Questionnaire (adapted from Dreher} \& Ash, 1990)

The questionnaire of Dreher and Ash (1990) was used as a foundation for developing this questionnaire, also supported by the theory of Kram (1988) - the nine roles of a mentor - and it was a shorter version of Noe's (1988) questionnaire based on the same theory. Twenty-nine items in question format were included in this questionnaire. No information on the reliability is available on this instrument, but findings of this study will be reported under the results section.

The first three questions were based on the fact that the respondent has a mentor. Questions 1a, 1b were about the type of mentorship and question 2 was about the mentor phase in which the protégé currently finds himself/herself. Question 3 was about the mentor's age. From question 4 , the questions were phrased in such a way that everybody could answer them regardless of whether they had a mentor or not. The questionnaire has a five-point intensity scale. Question 4 to question 6 was about the quality of the mentorship and the frequency of the interactions. The rest of the 29 items were based on the nine roles of a mentor (Kram, 1988).

Cited below are examples of two items in question-format and their response scales:

Question G6:

To what extent should a mentor protect one from working with other managers before one is informed about their opinion on controversial topics?

\section{To no extent}

\begin{tabular}{|l|l|l|l|l|}
\hline 1 & 2 & 3 & 4 & 5 \\
\hline
\end{tabular}

To a very large extent

\section{Question G10:}

To what extent should a mentor give one challenging assignments that present opportunities to improve one's competence?

To no extent

\begin{tabular}{|l|l|l|l|l|}
\hline 1 & 2 & 3 & 4 & 5 \\
\hline
\end{tabular}

To a very large extent 
No information on the reliability is available on this instrument. This instrument seems to have content and face validity based on the item content.

\section{Research procedure}

The measuring instrument was distributed via the organisation's intranet to all individuals in the division, excluding those on the lowest levels who were not able to read or write. A hard copy was also sent to employees via Human Resources Practitioners. All the ethical codes, e.g. control procedures, were adhered to. A letter of reminder was sent at a later stage to urge individuals to participate in the study. Individuals could respond anonymously and all the returned responses were treated with the utmost confidentiality. The identity (anonymity) of all the individuals was thus protected to ensure reliable responses.

\section{RESULTS}

The item distribution statistics are displayed in Table 3. Item distribution curves are slightly negatively skewed (based on negative skewness coefficients) and mesokurtic.

TABLE 3

DESCRIPTIVE STATISTICS OF THE MENTORSHIP ROLE QUESTIONNAIRE

\begin{tabular}{|c|c|c|c|c|c|c|c|}
\hline \multicolumn{8}{|c|}{$\mathrm{N}$} \\
\hline & Valid & Missing & Mean & Median & Mode & Skewness & Kurtosis \\
\hline G4 & 636 & 1 & 3,74 & 4,00 & 5,00 & $-0,876$ & $-0,227$ \\
\hline G5 & 636 & 1 & 3,67 & 4,00 & 4,00 & $-0,913$ & 0,408 \\
\hline G6 & 636 & 1 & 3,90 & 4,00 & 4,00 & $-1,119$ & 0,657 \\
\hline G7 & 636 & 1 & 3,62 & 4,00 & 4,00 & $-0,685$ & 0,034 \\
\hline G8 & 636 & 1 & 3,65 & 4,00 & 5,00 & $-0,725$ & $-0,256$ \\
\hline G9 & 636 & 1 & 3,52 & 4,00 & 4,00 & $-0,603$ & $-0,099$ \\
\hline G10 & 635 & 2 & 3,77 & 4,00 & 4,00 & $-0,985$ & 0,520 \\
\hline G11 & 635 & 2 & 3,23 & 3,00 & 4,00 & $-0,517$ & $-0,409$ \\
\hline G12 & 636 & 1 & 3,77 & 4,00 & 4,00 & $-1,038$ & 0,727 \\
\hline G13 & 636 & 1 & 3,66 & 4,00 & 4,00 & $-0,800$ & 0,190 \\
\hline G14 & 636 & 1 & 3,97 & 4,00 & 5,00 & $-1,186$ & 0,830 \\
\hline G15 & 636 & 1 & 3,71 & 4,00 & 4,00 & $-0,762$ & 0,056 \\
\hline G16 & 636 & 1 & 3,19 & 3,00 & 3,00 & $-0,399$ & $-0,566$ \\
\hline G17 & 636 & 1 & 3,51 & 4,00 & 4,00 & $-0,574$ & $-0,525$ \\
\hline G18 & 636 & 1 & 3,73 & 4,00 & 4,00 & $-0,789$ & $-0,044$ \\
\hline G19 & 636 & 1 & 3,56 & 4,00 & 4,00 & $-0,624$ & $-0,152$ \\
\hline G20 & 636 & 1 & 3,85 & 4,00 & 4,00 & $-1,023$ & 0,443 \\
\hline G21 & 636 & 1 & 3,63 & 4,00 & 4,00 & $-0,787$ & 0,256 \\
\hline G22 & 636 & 1 & 3,55 & 4,00 & 4,00 & $-0,596$ & $-0,238$ \\
\hline G23 & 636 & 1 & 3,87 & 4,00 & 5,00 & $-0,997$ & 0,381 \\
\hline G24 & 636 & 1 & 3,37 & 4,00 & 4,00 & $-0,516$ & $-0,542$ \\
\hline G25 & 636 & 1 & 3,32 & 3,00 & 3,00 & $-0,386$ & $-0,529$ \\
\hline G26 & 636 & 1 & 2,94 & 3,00 & 3,00 & $-0,133$ & $-0,821$ \\
\hline G27 & 636 & 1 & 2,70 & 3,00 & 3,00 & 0,283 & $-0,565$ \\
\hline G28 & 636 & 1 & 3,06 & 3,00 & 3,00 & $-0,025$ & $-0,773$ \\
\hline G29 & 636 & 1 & 3,58 & 4,00 & 4,00 & $-0,714$ & $-0,094$ \\
\hline
\end{tabular}

In order to determine the sampling adequacy and sphericity of the item intercorrelation matrix, the Kaiser-Meyer-Olkin (KMO) Measure of Sampling Adequacy (MSA) and Bartlett's Test of sphericity were respectively conducted on the item intercorrelation matrix of the instrument. A result of 0,6 and higher is required from the MSA to be acceptable (Hair, Anderson, Tatham \& Black, 1998). Three items were omitted at this stage, leaving 26 items in the scale. The results are reported in Table 4 . From Table 4 it is clear that matrix is suitable for further factor analysis.
TABLE 4

KMO AND BARTLETT'S TEST OF THE ITEM INTERCORRELATION MATRIX OF THE MENTORSHIP ROLE QUESTIONNAIRE

Kaiser-Meyer-Olkin Measure of Sampling

Adequacy

Bartlett's Test of Sphericity

Approx. Chi-Square 15392,06

df

Sig.

0,000

First level factor analysis

The eigenvalues of the unreduced item intercorrelation matrix were calculated. Two factors were postulated according to Kaiser's (1970) criterion (eigenvalues-greater-than-unity) (The eigenvalues of the unreduced item intercorrelation matrix are given in Table 5) and extracted by means of Principal Axis Factoring. The two factors explained about $67 \%$ of the variance in the factor space.

TABLE 5

EIGENVALUES OF THE UNREDUCED ITEM INTERCORRELATION MATRIX OF THE MENTORSHIP ROLE OUESTIONNAIRE

\begin{tabular}{|c|c|c|c|}
\hline \multicolumn{4}{|c|}{ Initial Eigenvalues } \\
\hline Factor & Total & $\%$ of Variance & Cumulative \% \\
\hline G1 & $\underline{15,448}$ & $\underline{59,414}$ & $\underline{59,414}$ \\
\hline G2 & $\underline{1,913}$ & $\underline{7,357}$ & $\underline{66,771}$ \\
\hline G3 & 0,939 & 3,611 & 70,382 \\
\hline G4 & 0,843 & 3,243 & 73,625 \\
\hline G5 & 0,724 & 2,785 & 76,411 \\
\hline G6 & 0,538 & 2,070 & 78,481 \\
\hline G7 & 0,479 & 1,844 & 80,325 \\
\hline G8 & 0,453 & 1,742 & 82,067 \\
\hline G9 & 0,444 & 1,709 & 83,776 \\
\hline G10 & 0,394 & 1,515 & 85,291 \\
\hline G11 & 0,372 & 1,430 & 86,721 \\
\hline G12 & 0,343 & 1,319 & 88,041 \\
\hline G13 & 0,315 & 1,213 & 89,253 \\
\hline G14 & 0,292 & 1,123 & 90,376 \\
\hline G15 & 0,280 & 1,078 & 91,454 \\
\hline G16 & 0,275 & 1,059 & 92,513 \\
\hline G17 & 0,258 & 0,991 & 93,504 \\
\hline G18 & 0,237 & 0,913 & 94,417 \\
\hline G19 & 0,222 & 0,854 & 95,271 \\
\hline G20 & 0,211 & 0,810 & 96,081 \\
\hline G21 & 0,203 & 0,783 & 96,864 \\
\hline G22 & 0,191 & 0,736 & 97,600 \\
\hline G23 & 0,181 & 0,698 & 98,298 \\
\hline G24 & 0,166 & 0,640 & 98,938 \\
\hline G25 & 0,157 & 0,602 & 99,541 \\
\hline G26 & 0,119 & 0,459 & 100,000 \\
\hline
\end{tabular}

Trace $=26$

The factor matrix obtained was rotated and sorted to a simple structure by means of varimax rotation (see Table 6). Only items with values greater than 0,3 were reported. 
TABLE 6

SORTED AND ROTATED FACTOR MATRIX OF THE MENTORSHIP ROLE QUESTIONNAIRE

\begin{tabular}{lcc}
\hline & & Factor \\
\hline & 1 & 2 \\
\hline G10 & 0,868 & \\
G12 & 0,845 & \\
G6 & 0,842 & 0,366 \\
G13 & 0,756 & 0,372 \\
G7 & 0,739 & 0,338 \\
G5 & 0,738 & 0,387 \\
G20 & 0,734 & 0,376 \\
G14 & 0,734 & 0,486 \\
G23 & 0,698 & 0,308 \\
G4 & 0,688 & 0,464 \\
G9 & 0,679 & 0,486 \\
G18 & 0,632 & 0,549 \\
G15 & 0,471 \\
G21 & 0,456 \\
G8 & 0,627 & 0,545 \\
G19 & 0,625 & 0,428 \\
G29 & 0,602 & 0,809 \\
G26 & 0,580 & 0,768 \\
G25 & 0,575 & 0,677 \\
G28 & & 0,672 \\
G27 & 0,364 & 0,660 \\
G24 & & 0,650 \\
G17 & 0,599 \\
G16 & 0,586 \\
G22 & 0,570 \\
G11 & 0,482 & \\
\hline
\end{tabular}

Extraction Method: Principal Axis Factoring.

Rotation Method: Varimax with Kaiser Normalisation.

The rotation converged in 3 iterations.

Second level factor analysis

Sub-scores were calculated on the two obtained factors and they were subsequently intercorrelated. The Kaiser-MeyerOlkin Measure of Sampling Adequacy and Bartlett's Test of Sphericity were not repeated here because only two factors were extracted.

During the second level factor analysis, eigenvalues were calculated and Kaiser's (1970) criterion (eigenvalues-greaterthan-unity) was applied and only one factor was postulated. The eigenvalues of the unreduced subscore intercorrelation matrix appear in Table 7. From Table 7, it can be seen that the one postulated factor explains about $90 \%$ of the variance in the factor space.

TABLE 7

EIGENVALUES OF THE UNREDUCED SUB-SCORE INTERCORRELATION MATRIX OF THE MENTORSHIP ROLE QUESTIONNAIRE

\begin{tabular}{lccc}
\hline+ & \multicolumn{3}{c}{ Initial Eigenvalues } \\
\hline Factor & Total & \% of Variance & Cumulative \% \\
\hline 1 & 1,795 & 89,769 & 89,769 \\
2 & 0,205 & 10,231 & 100,000 \\
\hline
\end{tabular}

The sorted and rotated factor matrix appears in Table 8 and it is apparent that both sub-factors have equally high factor loadings.
TABLE 8

SORTED AND ROTATED FACTOR MATRIX OF THE MENTORSHIP ROLE QUESTIONNAIRE

\begin{tabular}{lcc}
\hline Sub-scores & $\begin{array}{c}\text { Factor } \\
\text { I }\end{array}$ & $\begin{array}{c}\text { Communalities } \\
\text { Extraction }\end{array}$ \\
\hline (Factor 2) G: Mentor & 0,891 & 0,795 \\
(Factor 1) G: Mentor & 0,891 & 0,795 \\
\hline Fxtraction Method: Principal Axis Factoring. & &
\end{tabular}

Extraction Method: Principal Axis Factoring.

1 Factor extracted. 8 iterations required.

Iterative reliability analysis

The results obtained from the iterative reliability analysis on the Mentorship Role Questionnaire yielded a Cronbach Alpha of 0,9718, indicating a highly acceptable reliability. See Table 9.

TABLE 9

ITERATIVE ITEM ANALYSIS: THE MENTORSHIP ROLE QUESTIONNAIRE

\begin{tabular}{lccccc}
\hline Item & $\begin{array}{c}\text { Scale mean } \\
\text { if item } \\
\text { deleted }\end{array}$ & $\begin{array}{c}\text { Scale } \\
\text { variance if } \\
\text { item deleted }\end{array}$ & $\begin{array}{c}\text { Corrected } \\
\text { item }- \\
\text { Total } \\
\text { correlation }\end{array}$ & $\begin{array}{c}\text { Squared } \\
\text { multiple } \\
\text { correlation }\end{array}$ & $\begin{array}{c}\text { Alpha } \\
\text { if item } \\
\text { deleted }\end{array}$ \\
\hline G10 & 88,2835 & 495,1403 & 0,7655 & 0,8075 & 0,9706 \\
G12 & 88,2898 & 494,1146 & 0,8011 & 0,8122 & 0,9704 \\
G6 & 88,1591 & 495,0740 & 0,7443 & 0,7725 & 0,9707 \\
G13 & 88,3921 & 493,6835 & 0,8015 & 0,7448 & 0,9704 \\
G7 & 88,4378 & 493,3506 & 0,7934 & 0,7189 & 0,9704 \\
G5 & 88,3811 & 494,9744 & 0,7723 & 0,7224 & 0,9706 \\
G20 & 88,2094 & 492,0491 & 0,7961 & 0,7529 & 0,9704 \\
G14 & 88,0819 & 493,2425 & 0,7881 & 0,7272 & 0,9704 \\
G23 & 88,1890 & 490,0589 & 0,8351 & 0,7565 & 0,9701 \\
G4 & 88,3134 & 492,2281 & 0,7154 & 0,6780 & 0,9710 \\
G9 & 88,5354 & 493,2838 & 0,8085 & 0,7316 & 0,9703 \\
G18 & 88,3213 & 492,3004 & 0,7856 & 0,7100 & 0,9705 \\
G15 & 88,3465 & 492,0344 & 0,8213 & 0,7404 & 0,9702 \\
G21 & 88,4283 & 495,1979 & 0,7691 & 0,6660 & 0,9706 \\
G8 & 88,4031 & 492,3041 & 0,7465 & 0,6196 & 0,9707 \\
G19 & 88,4961 & 493,1873 & 0,7841 & 0,7000 & 0,9705 \\
G29 & 88,4740 & 496,1235 & 0,7078 & 0,5465 & 0,9710 \\
G26 & 89,1213 & 498,5894 & 0,6395 & 0,6789 & 0,9715 \\
G25 & 88,7307 & 493,5220 & 0,7567 & 0,7046 & 0,9707 \\
G28 & 88,9937 & 499,6750 & 0,6102 & 0,6224 & 0,9717 \\
G27 & 89,3575 & 504,0723 & 0,5433 & 0,5769 & 0,9722 \\
G24 & 88,6882 & 495,0509 & 0,6989 & 0,6427 & 0,9711 \\
G17 & 88,5433 & 490,8700 & 0,7601 & 0,6781 & 0,9706 \\
G16 & 88,8661 & 498,4978 & 0,6611 & 0,5527 & 0,9713 \\
G22 & 88,5102 & 493,5847 & 0,7696 & 0,6645 & 0,9706 \\
G11 & 88,8252 & 496,1918 & 0,7256 & 0,6134 & 0,9709 \\
\hline G & & & & & \\
\hline
\end{tabular}

$\mathrm{N}$ of cases $=637$

$\mathrm{N}$ of items $=26$

Cronbach Coefficient Alpha $=0,9718$

The iterative item analyses further indicate that total score means vary between 88,08 and 89,12 , somewhat above the total score midpoint (52). The item-total score correlations vary between 0,54 and 0,83 . The item reliability coefficients vary between 0,9701 to 0,9722 and the internal consistency of the scale yielded a Cronbach alpha of 0,97 . This concludes the results on the Mentorship Role Questionnaire.

\section{DISCUSSION}

In the construction of the instrument, the theoretical model proposed by Kram (1988) [studies that support Kram's work 
include Burke (1984); Gibb and Megginson (1993); Noe (1988a); Olian et al. (1988); Scandura (1992) and Schockett and Haring-Hidore (1985)], was used as a foundation for constructing this instrument. Items in the questionnaire were formulated in such a way that all the dimensions (subdomains) of the theoretical construct were systematically covered - a prerequisite for sound questionnaire construction (cf. Swart, Roodt \& Schepers, 1999). This procedure has ensured that the content validity (a facet of construct validity) as well as the face validity of the instrument was established (Foxcroft \& Roodt, 2004).

An important assumption often made in the construction of psychometric tests is that the items in the test form a linear scale. This assumption of the dimensionality of the vector space of test items must first be tested. Schepers (2004) suggested that if it turns out to be multidimensional, the test must first be categorised according to the construct to be measured. The categorisation can be done with the aid of factor analysis, but the procedure is not free of problems (Schepers, 2004).

This procedure for overcoming the effects of differential item skewness as proposed by Schepers (2004) was followed in the factor analyses of this study. Before proceeding with the first level factor analysis on the item intercorrelation matrix, two tests (the Kaiser-Meyer-Olkin Measure of Sampling Adequacy and the Bartlett's Test) were conducted to test the suitability of the matrix for factor analysis. After establishing the affirmative, eigenvalues were calculated on the unreduced matrix and two factors were postulated based on the eigenvalues larger than unity.

Subscores were calculated on each of these postulated factors but owing to the fact that only two factors were extracted tests for the suitability of the matrix for further factor analysis were not again repeated. Eigenvalues were again calculated on the unreduced subscore intercorrelation matrix and one factor was postulated. Only one factor was extracted by using Principal Axis factoring. The one extracted factor suggests that the Mentorship Role Questionnaire complies with the requirements of factorial validity, a sub-component of construct validity (Allen \& Yen, 1979).

The statistical analyses were concluded by iterative item analyses on the scale. The obtained Cronbach alpha of 0,97 confirms the high internal consistency of the scale, suggesting that the measuring instrument is capable of consistently reflecting the same underlying constructs. Furthermore, it indicates a high degree of homogeneity between the questionnaire items. These obtained reliability coefficients suggest that the scale measures the mentorship role construct with a low standard error of measurement (SEM).

Based on the above discussion, it seems as if the Mentorship Role Questionnaire has acceptable metric properties as it succeeded in measuring the mentorship role construct in a reliable and consistent manner. Hereby the primary objective of the study was met.

No analyses were conducted to give an indication of the scale's differential (discriminant) validity, a facet of construct validity. Future research can address this issue by comparing different groups that were composed on expected $a$ priori differences.

It seems as if the newly constructed instrument can play a valuable role in identifying and developing prospective mentors for this key role in organisations and also to identify their comparative training and development needs. In doing so, this instrument can assist in developing South Africa's much needed black management talent and thereby improving the effectiveness and efficiency of South African companies to enhance much needed economic growth.

\section{REFERENCES}

Allen, M.J. \& Yen, W.M. (1979). Introduction to Measurement Theory. Monterey, California: Brooks/Cole Publishing.

Allen, T.D., Poteet, M.L. \& Burroughs, S.M. (1997). The mentor's perspective: A qualitative inquiry and future research agenda. Journal of Vocational Behavior, 51, 70-89.

Alperson, M. (1993). Woman experiences of Affirmative Action. In D. Innes, M. Kentridge \& H. Perold (Eds), Reversing discrimination: Affirmative action in the workplace (pp. 205212). Cape Town: Oxford University Press.

April, A. (1979). Teaching the ropes: The growing popularity of coaching/mentoring. Convergence, 3 (3), 44-48.

Atkinson, D.R., Neville, H. \& Casas, A. (1991). The mentorship of ethnic minorities in professional psychology. Professional Psychology: Research and Practice, 22, 336-338.

Bass, B.M. (1990). Bass and Stogdill's handbook of leadership. New York: The Free Press.

Blake, S.D. (1995). At the crossroads of race and gender: Lessons from the mentoring experiences of professional Black women. Paper presented at the National Academy of Management Meeting, Vancouver, British Columbia, Canada.

Blau, F.D. \& Ferber, M.A. (1987). Occupations and earnings of women workers. In K.S. Koziara, M.H. Moskow \& L.D. Tanner (Eds), Working women: Past, present, future (pp. 3768). Washington, DC: Bureau of National Affairs, Inc.

Bowen, D.D. (1985). Were men meant to mentor women? Training and Development Journal, 2, 31-34.

Brass, D.J. (1985). Men's and women's networks: A study of interaction patterns and influence in an organization. Academy of Management Journal, 28, 327-343.

Brefach, S.M. (1986). The mentor experience: The influences of female/male mentors on the personal and professional growth of female psychologists. Unpublished doctoral dissertation. Boston: Boston University.

Brown, D.A. (1986). The role of mentoring in the professional lives of university faculty women. Dissertation Abstracts International, 47, 160A.

Burke, R.J. (1983). Mentors in organizations: Managers as teachers. Unpublished paper. Oklahoma: Oklahoma Organizational Behaviour Teaching Conference.

Burke, R.J. (1984). Mentors and organizations. Group and Organization Studies, 9, 253-272.

Burke, R.J. \& McKeen, C.A. (1989). Developing formal mentoring programs in organizations. Business Quarterly, 53, 76-99.

Burke, R.J., McKeen, C.A. \& McKenna, C. (1993). Correlates of mentoring in organizations: The mentor's perspective. Psychological Reports, 72, 883-896.

Burke, R.J., McKenna, C. \& McKeen, C.A. (1991). How do mentorship differ from typical supervisory relationships? Psychological Reports, 68, 459-466.

Chao, G.T. (1997). Mentoring phases and outcomes. Journal of Vocational Behaviour, 51, 15-28.

Chao, G.T., Walz, P.M. \& Gardner, P.D. (1992). Formal and informal mentorships: A comparison on mentoring functions and contrast with nonmentored counterparts. Personnel Psychology, 45, 619-636.

Clawson, J.G. (1980). Mentoring in managerial careers. In C.B. Derr (Ed.), Work, family and career: New frontiers in theory and research (pp. 36-39). New York: Praeger Publishers.

Clawson, J.G. (1985). Is mentoring necessary? Training and Development Journal, April, 36-39.

Clutterbuck, D. \& Abbott, P. (2003). Mentoring as an empowerment tool. People Dynamics, 21 (4), April, 24-25.

Clutterbuck, D. \& Devine, M. (1987). Businesswoman. Basingstoke: Macmillan.

Clutterbuck, D. \& Megginson, D. (1999). Mentoring executives and directors. Oxford: Butterworth Heinemann.

Cohen, N.H. (1999a). The mentee's guide to mentoring. Amherst, Massachusetts: HRD Press.

Cohen, N.H. (1999b). The manager's pocket guide to effective mentoring. Amherst, Massachusetts: HRD Press. 
Daily, C.M., Certo, S.T. \& Dalton, D.R. (2000). The future of corporate women. In R.J. Burke \& M.C. Mattis (Eds), Women on corporate boards of directors: International challenges and opportunities (pp. 11-23). Dordrecht: Kluwer Academic Publishers.

Dinsdale, R. (1990). Formal mentorship: Building effective future managers. Human Resource Management, February, 26-28.

Douglas, C.A. (1997). Formal mentoring programs in organizations: An annotated bibliography. Greensboro, NC: Center for Creative Leadership.

Douglas, C.A. \& Schoorman, F.D. (1988). The impact of career and psychosocial mentoring by supervisors and peers. Paper presented at the 1988 Academy of Management Meeting, Anaheim, CA.

Dreher, G.F. \& Ash, R.A. (1990). A comparative study of mentoring among men and women in managerial, professional and technical positions. Journal of Applied Psychology, 75 (5), 539-546.

Eby, L.T. (1997). Alternative forms of mentoring in changing organizational environments: A conceptual extension of the mentoring literature. Journal of Vocational Behavior, 51, 125-144.

Ensher, E.A. \& Murphy, S.E. (1997). Effects of race, gender, perceived similarity and contact on mentor relationships. Journal of Vocational Behavior, 50, 460-481.

Erkut, S. \& Mokros, J.R. (1984). Professors as models and mentors for college students. American Educational Research Journal, 21 (2), 399-417.

Fagenson, E.A. (1988). The power of a mentor: Protégés' and nonprotégés' perceptions of their own power in organizations. Group and Organization Studies, 13, 182-194.

Fagenson, E.A. (1989). The mentor advantage: Perceived career/job experiences of protégés versus non-protégés. Journal of Organizational Behavior, 10, 309-320.

Fagenson, E.A. (1992). Mentoring - Who needs it? A comparison of protégés and nonprotégés' needs for power, achievement, affiliation and autonomy. Journal of Vocational Behavior, 41, 48-60.

Fagenson, E.A. (1994). Perceptions of protégés' vs. nonprotégés' relationships with their peers, superiors and departments. The Journal of Vocational Behavior, 45, 55-78.

Fagenson-Eland, E.A., Marks, M.A. \& Amendola, K.L. (1997). Perceptions of mentoring relationships. Journal of Vocational Behavior, 51, 29-42.

Foxcroft, C. \& Roodt, G. (2004). An introduction to psychological assessment in the South African context. Cape Town: Oxford University Press.

Fracaro, K. (2002). Mentoring: Tool for career guidance. Supervision, 63 (9), September, 10-12.

Furano, K., Roaf, P.A., Styles, M.B. \& Branch, A.Y. (1993). Big brothers/sisters: A study of program practices. Philadelphia, PA: Public/Private Ventures.

Garcia, M. (1992). Mentoring the new graduate at Jet Propulsion Laboratory (pp. 162-171). Proceedings of the Diversity in Mentoring Conference, Chicago, IL, Western Michigan University.

Gaskill, L.R. (1993). A conceptual framework for the development, implementation and evaluation of formal mentoring programs. Journal of Career Development, 20, 147-160.

Geiger-DuMond, A.H. \& Boyle, S.K. (1995). Mentoring: A practitioner's guide. Training and Development, 49, 51-54.

Gibb, S. \& Megginson, D. (1993). Inside corporate mentoring schemes: A new agenda of concerns. Personnel Review, 22, 40-54.

Goleman, D. (1996). Emotional intelligence. London: Bloomsbury.

Green, S.G. \& Bauer, T.N. (1995). Supervisory mentoring by advisors: Relationships with doctoral student potential, productivity and commitment. Personnel Psychology, 48, 537-561.

Gunn, E. (1995). Mentoring: The democratic version. Training, 32 (8), August, 64-67.
Hair, J.F. Jr., Anderson, R.E., Tatham, R.L. \& Black, W.C. (1998). Multivariate data analysis ( $5^{\text {th }}$ edition). Upper Saddle River, NJ: Prentice-Hall International.

Hendrikse, J. (2003). Personal communication: Mentorship. April 9. Johannesburg: Spoornet.

Hissong, D. (1993). Excel in your engineering. Chemical Engineering, 100, 157-160.

Hofmeyer, K.B. (1987). Can mentorship be institutionalized? IPM Journal, April, 13-15.

Hunt, D. (1991). Mentorship: The path to success. Boardroom, 3, 23-25.

Hunt, D. \& Michael, C. (1983). Mentorship: A career training and development tool. Academy of Management Review, 8 (3), 475-485.

Ivancevich, J.M. \& Matteson, M.T. (1996). Organisational behavior and management (4th edition). Chigago: Irwin.

Jacobi, M. (1991). Mentoring and undergraduate success: A literature review. Review of Educational Research, 61, 505-532.

Janse van Rensburg, K. (2004). A predictive model of employee commitment in an organisation striving to become world-class. Unpublished D. Litt. Et Phil. thesis. Johannesburg: Rand Afrikaans University.

Kaiser, H.F. (1970). A second-generation Little Jiffy. Psychometrika, 35, 401-415.

Kanter, R.M. (1977). Men and women of the corporation. New York: Basic Books.

Kayle, B. \& Jacobson, B. (1995). Mentoring: A group guide. Training and Development, 49 (4), April, 23-27.

Kerkes, D.J. (1994). Precepts of project management. Civil Engineering, 64, 70-72.

Kram, K.E. (1983). Phase of the mentor relationship. Academy of Management Journal, 26, 608-625.

Kram, K.E. (1985). Improving the mentoring process. Training and Development Journal, April, 40-43.

Kram, K.E. (1988). Mentoring at work: Developmental relationships in organizational life. Lanham: University Press of America.

Kram, K.E. \& Isabella, L.A. (1985). Mentoring alternatives: The role of pure relationships in career development. Academy of Management Journal, 28 (1), 110-132.

Levinson, D.J., Darrow, C.N., Klein, E.B., Levinson, M.A. \& McKee, B. (1978). Seasons of a man's life. New York: Knopf.

Marien, B.A. (1992). Quality in R\&D: Putting TQM into the performance review process. Research Technology Management, 35, 39-43.

McGregor, A. (1993). A holistic approach to affirmative action. In D. Innes, M. Kentridge \& H. Perold (Eds), Reversing discrimination: Affirmative action in the workplace (pp. 95105). Cape Town: Oxford University Press.

Mullen, E. (1994). Framing the mentoring relationship in an information exchange. Human Resource Management Review 4, 257-281.

Murray, M. (1991). Beyond the myths and magic of mentoring: How to facilitate an effective mentoring program. San Francisco: Jossey-Bass.

Noe, R.A. (1988a). An investigation of the determinants of successful assigned mentoring relationships. Personnel Psychology, 41, 457-479.

Noe, R.A. (1988b). Women and mentoring: A review and research agenda. Academy of Management Review, 13 (1), 65-78.

Olian, J.D., Carroll, S.J. \& Giannantonio, C.M. (1993). Mentor reactions to protégés: An experiment with managers. Journal of Vocational Behaviour, 43, 266-278.

Olian, J.D., Carroll, S.J., Giannantonio, C.M. \& Feren, D.B. (1988). What do protégés look for in a mentor? Results of three experimental studies. Journal of Vocational Behavior 33, 15-37.

Orpen, C. (1995). The effects of mentoring on employees career success. Journal of Social Psychology, 135, 667-668.

Orth, C.D., Wilkinson, H.E. \& Benfari, R.C. (1987). The manager's role as coach and mentor. Organization Dynamics, $15,66-74$ 
Owen, M.A. (1991). Beyond the myths and magic of mentoring. Oxford: Jossey-Bass.

Parker, V.A. \& Kram, K.E. (1993). Women mentoring women: Creating conditions for connection. Business Horizons, 36 (2), 42-51.

Parson, R.J. (1991). Enlightened management must lay a strong foundation in training new engineers. Industrial Engineering, 23, 34-38.

Phillips-Jones, L. (1982). Mentors and protegés. New York: ArborHouse.

Phillips-Jones, L. (1983). Establishing a formalized mentoring program. Training Development Journal, February, 38-42.

Ragins, B.R. (1989). Barriers to mentoring: The female managers' dilemma. Human Relations, 42, 1-22.

Ragins, B.R. (1997). Antecedents of diversified mentoring relationships. Journal of Vocational Behavior, 51, 90-109.

Ragins, B.R. \& Cotton, J.L. (1999). Mentor functions and outcomes: A comparison of men and women in formal and informal mentoring relationships. Journal of Applied Psychology, 84 (4), 529-550.

Ragins, B.R. \& McFarlin, D.B. (1990). Perception of mentor roles in cross-gender mentoring relationships. Journal of Vocational Behavior, 37, 321-339.

Ragins, B.R. \& Scandura, T.A. (1994). Gender differences in expected outcomes of mentoring relationships. Academy of Management Journal, 37 (4), 957-971.

Riley, S. \& Wrench, D. (1985). Mentoring among female lawyers. Journal of Applied Social Psychology, 15, 374-386.

Roche, G. (1979). Much ado about mentors. Harvard Business Review, 57 (1), 14-28.

Rogers, B. (1992). Mentoring: Takes a new twist. Human Resource Magazine, August, 48-51.

Scandura, T.A. (1992). Mentorship and career mobility: An empirical investigation. Journal of Organizational Behavior, 13, 169-174.

Scandura, T.A. \& Schriesheim, C.A. (1994). Leader-member exchange and supervisor career mentoring as complementary constructs in leadership research. Academy of Management Journal, 37, 1588-1602.

Schepers, J.M. (2004). Overcoming the effects of differential item skewness of test items in scale construction. SA Journal of Industrial Psychology, 30 (4), 27-43.

Schockett, M. \& Haring-Hidore, M. (1985). Factor analytic support for psycho-social and vocational mentoring functions. Psychological Reports, 57, 627-630.
Singh, V., Bains, D. \& Vinnicombe, S. (2002). Informal mentoring as an organisational resource. Long Range Planning, 35, 389-405.

Storm, L. \& Roodt, G. (2002). Die verband tussen organisasiesosialisering en organisasieverbondenheid (The relationship between organisation socialisation and organisation commitment). SA Journal of Industrial Psychology, 28 (1), $14-21$.

Swart, C., Roodt, G. \& Schepers, J.M. (1999). Item formaat, differensiële item skeefheid en die faktorstruktuur van 'n selfvoltooiingsvraelys (Item format, differential item skewness and the factor structure of a self-completion questionnaire). Journal of Industrial Psychology, 25 (1), 33-43.

Tack, W.L. \& Tack, L. (1986). Don't ignore seasoned managers: The case for management cycling. Sloan Management Review, $27,63-70$

Thomas, D.A. (1990). The impact of race on manager's experiences of developmental relationships (mentoring and sponsorship): An intra-organizational study. Journal of Organizational Behavior, 11, 479-492.

Thomas, D.A. \& Alderfer, C.P. (1989). The influence of race on career dynamics: Theory and research on minority career experiences. In M.B. Arthur, D.T. Hall \& B. Lawrence (Eds), Handbook of career theory (pp. 133-158). Cambridge, MA: Cambridge University Press.

Ueckermann, H. (2004). Te min vroue in sleutelposisies (To few women in key positions). City Press Careers, May 2, 1.

Viator, R.E. (2000). The association of formal and informal public accounting mentoring with role stress and related job outcomes. Accounting, Organizations and Society, 26 (1), 73-93.

Walbrugh, A. \& Roodt, G. (2003). Different age groups response to employee equity practices. SA Journal of Human Resource Management, 1 (2), 28-39.

Warihay, P.D. (1980). The climb to the top: Is the network the route for women? Personnel Administrator, 25 (4), 55-60.

Whitely, W., Dougherty, T. \& Dreher, G. (1991). Relationship of career mentoring and socio-economic origin to managers and professionals early career progress. Academy of Management Journal, 34, 331-351.

Willbur, J. (1987). Does mentoring breed success? Training and Development Journal, 11, 38-41.

Wingrove, T. (2002). Mentoring challenges to sweeten the medicine. HR Future, 2 (11), November/December, 10-12.

Zey, M.G. (1985). Mentor programs: Making the right moves. Personnel Journal, 64 (2), 53-57. 